Doc. dr. sc. Dragan Zlatović, prof. v. š.

UDK: 347.6:343.615 (497.5)

Veleučilište u Šibeniku

Primljen: 16. 11. 2021.

zlatovic@vus.hr

Prihvaćen: 20. 12. 2021.

Stručni rad

\title{
PRAVNI OKVIR ZA STRATEGIJSKE DOKUMENTE RAZVOJA SPORTA I SPORTSKE REKREACIJE U REPUBLICI HRVATSKOJ
}

\begin{abstract}
Sažetak: Autor u radu pregledno analizira pravni okvir međunarodnog, europskog $i$ hrvatskog sportskog prava, kao podlogu za izradu strategija razvoja sporta na nacionalnoj razini i razini lokalne samouprave u Republici Hrvatskoj. U okviru rasprave o ovoj temi upućuje se na referentne odredbe revidiranog Zakona o sportu i kao i na svrhu i ciljeve novog Nacionalnog programa športa 2019. - 2026. U radu se finalno istražuju strateški dokumenti jedinica lokalne i područne (regionalne) samouprave u Republici Hrvatskoj u području razvoja sporta i sportske rekreacije, te ukazuje na potrebe nove zakonske i strategijske podloge na nacionalnoj razini.
\end{abstract}

Ključne riječi: sport, strategija sporta, Zakon o sportu, Olimpijska povelja, Europska povelja o sportu. 
"Sport je dio nasljedstva svakog muškarca $i$ žene $i$ njegovo odsustvo se nikada ne može nadoknaditi."

- Pierre de Coubertin*

\section{Sport u Republici Hrvatskoj - načela i modeli}

Sport ${ }^{\star}$, kako ga definira Europska povelja o sportu Vijeća Europe, ${ }^{1}$ predstavlja svaki oblik fizičke aktivnosti koja putem slučajnog ili organiziranog sudjelovanja ima cilj izraziti ili unaprijediti fizičku spremnost i mentalno blagostanje stvarajući socijalne odnose ili ostvarujući rezultate u natjecanjima na svim razinama.

Sport u Republici Hrvatskoj temelji se na načelu autonomije sporta i sportskih organizacija, što se odnosi na:

- autonomiju od svih utjecaja i miješanja politike, države ili treće strane u pitanja djelovanja i organizacije sporta;

- postizanje demokratskih standarda biranja i odlučivanja u sportskim tijelima svih razina;

- odgovarajuće financiranje iz javnih izvora i na raspodjelu i trošenje financijskih sredstava;

- donošenje, provedbu i tumačenje pravila koja se odnose na sport i sportske aktivnosti, koja ipak moraju biti u skladu s nacionalnim i međunarodnim zakonima. $^{2}$

1 Council of Europe, European Sports Charter, Adopted by the Committee of Ministers on 13 October 2021, CM/Rec(2021)5, dostupna na mrežnoj stranici https://rm.coe. $\mathrm{int} / \mathrm{recommendation-cm-rec-2021-5-on-the-revision-of-the-european-sport-}$ cha/1680a43914 (posjećeno 20. 12. 2021.).

Pierre de Coubertin (1863. - 1937.), francuski pedagog i povjesničar, utemeljitelj modernih olimpijskih igara

Termin sport potječe iz starog francuskog jezika, od glagola desport (desporter, deporter), što bi označavalo aktivnost u kojoj se uživa, kojom se neko zabavlja. Za porijeklo pojma sport, vidi: http://www.etymonline.com/index.php?search=sport\&searchmode=none, (posjećeno 30. 10. 2021.) U ranijoj zakonskoj terminologiji hrvatski zakonodavac je koristio izraz "šport”. Novelom Zakona o športu (NN. 86/2012) izraz “šport” je zamijenjen pojmom "sport". Autor je u ovom radu koristio sada važeće zakonske termine, pa tako i pojam „sport“. Kod navođenja izvornih zakonskih tekstova i radova iz toga vremena, autor je koristio tada važeće pojmove, uključujući i pojam „šport“.

2 O sportu i posebice sportskom pravu u Republici Hrvatskoj vidi kod SMOKVINA, V., Sports Law in Croatia, Kluwer Law International, Alphen aan den Rijn, 2017. 
U Republici Hrvatskoj, kao i u većini zemalja Europe i svijeta, karakterističan je piramidalni model sporta. Ovakav sustav podrazumijeva udruživanje subjekata na području jednog sporta, od najniže razine sportskih klubova koji se udružuju $\mathrm{u}$ regionalne sportske saveze pojedine države, a oni pak u nacionalne sportske saveze. Nacionalni sportski savezi za pojedini sport udružuju se u europske saveze koji su dijelom međunarodnog (svjetskog) udruženja za pojedini sport. Sportom na svjetskoj razini upravljaju međunarodna sportska udruženja, zasebno za svaki sport, a koja se opet udružuju u određene organizacije, među kojima je najveća i najutjecajnija SportAccord (do 2009. g. GAISF) u koju se udružuju međunarodna sportska udruženja olimpijskih i paraolimpijskih sportova. Na međunarodnoj je razini najutjecajnija sportska organizacija Međunarodni olimpijski odbor (MOO), iako su glavne zadaće olimpijskih odbora ograničene na organizaciju olimpijskih igara i promicanje olimpizma. Od europskih vladinih i nevladinih tijela koja djeluju na području organizacije, ustroja i pravnog uređenja sporta izdvaja se nekoliko značajnih tijela odnosno organizacija poput Vijeća Europe, Odjela sporta Opće uprave za obrazovanje i kulturu Europske komisije, ENGSO (European Non-Governmental Sports Organization).

Sportski klubovi (sportska udruga ili trgovačko društvo) temeljna su ustrojbena jedinica hrvatskoga sporta. Udruženi u lokalne i/ili nacionalne strukovne sportske saveze, kao i u lokalne sportske zajednice grade nevladinu piramidu sustava sporta. Na vrhu piramide nalazi se Hrvatski olimpijski odbor koji djeluje kao nacionalni olimpijski odbor, savez nacionalnih sportskih saveza te savez županijskih sportskih zajednica. Sa statusom nacionalnih sportskih saveza djeluju i Hrvatski savez sportske rekreacije „Sport za sve“, Hrvatski sveučilišni sportski savez, Hrvatski školski sportski savez, Hrvatski paraolimpijski odbor, Hrvatski sportski savez gluhih i Specijalna olimpijada Hrvatske. Vladinu piramidu sustava sporta čine županijski i gradski upravni odjeli kojima je sport u nadležnosti. Središnji državni ured za šport (do 2016. Uprava za sport u Ministarstvu znanosti, obrazovanja i sporta Republike Hrvatske) bio je do 2020. najviše Vladino tijelo u sastavu Ministarstva turizma i sporta, međutim, potom je ukinuto, pa je područje sporta inkorporirano u resor Ministarstva turizma i sporta RH. Nacionalno vijeće za sport najviše je stručno sportsko tijelo koje imenuje Sabor RH i koje se brine za razvoj i kvalitetu sporta u Republici Hrvatskoj.

\section{Strategijski dokumenti u sportu}

Riječ strategija dolazi od grčke riječi strategos, vojskovođa. U doslovnom prijevodu strategos znači „vođenje vojske“ (stratos = vojska, agein = voditi). S 
vremenom je to značenje riječi izgubljeno, a danas se u općem smislu pod strategijom podrazumijeva snalaženje u zadanim uvjetima i pronalaženje najboljih rješenja pod pretpostavkom da se jasno definiraju ciljevi koji se žele ostvariti te okviri i ograničenja za njihovo postizanje. ${ }^{3}$

U Republici Hrvatskoj ključni dokument promišljanja razvoja sporta i sportske rekreacije trebala bi biti Strategija razvoja sporta Republike Hrvatske. Taj dokument bi trebao biti polazna osnova za izradu zakona i podzakonskih akata i ostalih dokumenata niže razine. Na Strategiju razvoja sporta $\mathrm{RH}$ trebale bi se osloniti strategije Hrvatskog olimpijskog odbora (HOO), strategije razvoja nacionalnih sportskih saveza, strategije razvoja sporta županija i gradova, strategije razvoja sporta na sveučilištima te dugoročni planovi pojedinačnih sportskih klubova. ${ }^{4}$

Nažalost, nacionalna strategija razvoja sporta u RH dugi niz godina je prolongirana u donošenju, iako su odavno bili izrađeni polazni prijedlozi i smjernice (Strategija razvoja sporta u Hrvatskoj iz 1998., Prijedlog strategije razvoja hrvatskog sporta iz 2000., Temeljna načela i smjernice razvoja sporta u Republici Hrvatskoj iz 2011.).

Ipak, 2014. dolazi do pomaka u tom pogledu kada Hrvatski olimpijski odbor (HOO) objavljuje Nacionalni program sporta 2014. - 2020. u kojem vrlo jasno definira polazišta i ciljeve. HOO ističe kao glavne ciljeve: 1 . stvaranje uvjeta za ostvarivanje vrhunskih rezultata na velikim međunarodnim natjecanjima, 2. unapređenje međunarodnog statusa hrvatskog sporta, 3. poticanje održivih programa lokalnog sporta radi afirmiranja sporta kao bitnog čimbenika očuvanja zdravlja te razvoja gospodarstva, kulture i turizma, 4. poticanje unapređenja i izgradnje sportske infrastrukture kao pretpostavke razvoja sporta, 5. povećanje broja stručno osposobljenog kadra za rad u sportu i sportskoj rekreaciji i osiguranje kontinuiranog i kompatibilnog obrazovnog sustava u području sporta, 6. informiranje i komunikacija u funkciji popularizacije sporta, 7. povećanje zastupljenosti žena u sportu na svim razinama, 8. osiguravanje izvora financijskih sredstava za razvoj sporta i poticanje ulaganja u sport. Iako u svom nazivu ne sadrži eksplicitni naziv strategije, engo programa, ovaj dokument je strateške naravi kako je to i definirano čl. 2. Zakona o sportu.

3 Izvod iz Strategije razvoja sporta grada Karlovca 2021. - 2028. - Strateški dokument s akcijskim planom djelovanja u području sporta Grada Karlovca za razdoblje 2021. - 2028., Karlovac, 2020., dostupno na web stranici https://www.karlovac.hr/ UserDocsImages//2020\%20dokumenti//STRATEGIJA\%20RAZVOJA\%20SPORTA\%20 GRADA\%20KARLOVCA_30_10.pdf (posjećeno 12. 11. 2021.).

4 Tako LEKO, G., Primjeri dobre prakse na području sporta, 27. ljetna škola kineziologije Republike Hrvatske, Poreč, 27. - 30. 6. 2018., Zbornik radova, str. 52. 
Za svaki se od tih ciljeva jasno definiraju aktivnosti potrebne za realizaciju cilja, nositelji provedbe te pokazatelji učinka. Godinu dana kasnije objavljen je i Strateški plan HOO 2015. - 2022. (razvoj sporta i olimpijskog pokreta) koji može biti ogledni primjer dugoročnog promišljanja i planiranja razvoja

Nadalje, Vlada RH je na svojoj 160. sjednici od 6. lipnja 2019. usvojila Nacrt prijedloga Nacionalnog programa sporta 2019. - 2026., te ga uputila u saborsku proceduru, a kojim se želi uspostaviti mehanizam za postizanje nacionalnih ciljeva u sportu i jasno postaviti uloge, zadaće i odgovornosti svih partnera u lancu stvaranja sportskog rezultata, od sportaša i kluba, preko općine ili grada, županije i državne razine, nacionalnog sportskog saveza i krovnih udruženja pa do Središnjeg državnog ureda za šport odnosno nakon njegovog ukidanja do Ministarstva turizma i sporta RH. Ova inicijativa rezultirala je donošenjem Nacionalnog programa sporta 2019. - 2026. („Narodne novine“, br. 69/19.), koji je na snazi kao ključni strateški dokument u ovom području

Ovim Nacionalnim programom koji se donosi za osmogodišnje razdoblje utvrđuju se ciljevi razvoja sporta, mjere i aktivnosti potrebne za provedbu tih ciljeva te nositelji i provoditelji razvoja i mjere kontrole njegove provedbe kako je definirano člankom 2. stavkom 1. Zakona o sportu.

Nacionalni program sporta sukladno Zakonu o sportu sadržava:

- programe stvaranja uvjeta za bavljenje sportom u odgojno-obrazovnom sustavu,

- programe stvaranja uvjeta za postizanje vrhunskih rezultata hrvatskih sportaša na međunarodnim natjecanjima,

- programe stvaranja uvjeta za rekreativno bavljenje sportom radi zaštite i poboljšanja zdravlja građana Republike Hrvatske.

Nacionalni program sporta predstavlja sveobuhvatni strateški dokument o razvoju sporta u Republici Hrvatskoj i uporište je za izradu strateških dokumenata svih nacionalnih, regionalnih i lokalnih organizacija u sportu. Polazeći od analize stanja i detektiranih problema, metodološki pristup izradi Nacionalnog programa sporta Republike Hrvatske sagledava sport kao multidisciplinarnu pojavu, a zasniva se na sljedećim načelima:

- transparentnost planskog procesa,

- multidisciplinarnost pristupa,

- suradnja, uključivanje dionika i javnosti,

- susretno planiranje,

- utemeljenost na dostupnim podacima. 
Hrvatski sabor je na sjednici 12. srpnja 2019. donio Nacionalni program športa 2019. - 2026. („Narodne novine“, br. 69/19.). U njemu je posebno naglašeno kako je sport u Hrvatskoj već desetljećima iznimno važan segment društvenog života, ali segment o kome se vrlo rijetko strateški i cjelovito promišlja, te se apostrofira kao djelatnost od posebnog interesa za Republiku Hrvatsku. Nacionalni program športa 2019. - 2026. prema zdravoj i aktivnoj naciji ponosnoj na sportske uspjehe, prvi je razvojni akt planiranja i važno ishodište promišljanja i ostvarivanja budućnosti hrvatskog sporta.

Na temelju članka 1. stavka 2. Zakona o sportu, sportske djelatnosti su djelatnosti od posebnog interesa za Republiku Hrvatsku te je sukladno članku 2. navedenog Zakona bilo prijeko potrebno donošenje Nacionalnog programa športa, koji predstavlja temeljni razvojni akt planiranja kojim se uređuje razvoj i unaprjeđuje sustav sporta u Republici Hrvatskoj. Nacionalni program sporta donio je Hrvatski sabor na prijedlog Vlade Republike Hrvatske za razdoblje od osam godina te se njime utvrđuju ciljevi razvoja sporta, mjere i aktivnosti potrebne za provedbu tih ciljeva te nositelji i provoditelji razvoja i mjere kontrole njegove provedbe kako je definirano člankom 2. stavkom 1. Zakona o sportu.

Nacionalni program športa sukladno Zakonu o sportu sadrži:

- programe stvaranja uvjeta za bavljenje sportom u odgojno-obrazovnom sustavu,

- programe stvaranja uvjeta za postizanje vrhunskih rezultata hrvatskih sportaša na međunarodnim natjecanjima, te

- programe stvaranja uvjeta za rekreativno bavljenje sportom radi zaštite i poboljšanja zdravlja građana Republike Hrvatske.

Važna područja Nacionalnog programa športa su: definiranje načina upravljanja sportom, stvaranje uvjeta za poticanje ulaganja u sport te transparentno i namjensko trošenje sredstava, zatim briga o sportskim građevinama kroz izradu mreže sportskih građevina i poticanje izgradnje i održavanja sportskih građevina, kao i poticanje i reguliranje obrazovanja stručnih kadrova u sportu, briga o sportašima kao glavnim dionicima sporta te stvaranje uvjeta za rekreativno bavljenje sportom radi zaštite i poboljšanja zdravlja građana Republike Hrvatske. Dakle, iako do 2019. Republika Hrvatska nije imala dokument nacionalne strategije u području sporta, to nije obeshrabrilo određene lokalne sredine da u međuvremenu izrade svoje strateške dokumente u području sporta i sportske rekreacije (npr. Primorsko-goranska županija, gradovi Rijeka, Dubrovnik, Karlovac, Samobor, Pazin, Sinj i dr.) koje će morati usklađivati s nacionalnom strategijom i Nacionalnim programom. 
Pri izradi strategije razvoja sporta i sportske rekreacije na lokalnoj razini potrebno je definirati pravni okvir sportskog prava odnosno obavljanja sportske i drugih srodnih djelatnosti u Republici Hrvatskoj i konkretnoj sredini.

Primarni cilj i osnovni sadržaj ovog strateškog dokumenta je: 1) prikupiti i analizirati trenutne pokazatelje te precizno i utemeljeno odrediti aktualno stanje sporta u određenoj jedinici lokalne i područne (regionalne) samouprave na globalnoj razini i na razini svakog strateškog područja, 2) jasno i precizno odrediti buduće stanje koje se može postići u zadanom vremenu uz angažiranje raspoloživih resursa te - odrediti standarde i vrijednosti optimalnog stanja sporta u lokalnoj sredini u budućnosti u svim njegovim strateškim područjima, 3) izraditi strateški program razvoja koji će sadržavati: potrebne mjere, aktivnosti i načine djelovanja, rokove provedbe, praćenja i kontrole provođenja strateških ciljeva uz primjenu objektivnih indikatora uspješnosti, te vrednovanje postignuća u pojedinim vremenskim razdobljima.

U strategiji razvoja sporta na razini jedinice lokalne samouprave kao opći ciljevi trebali bi biti određeni: stvaranje svima prihvatljivog i održivog modela sporta, postizanje učinkovitijeg upravljanja i koordinacije u sportu, usmjerenost na dugoročne ciljeve, stvaranje kvalitetne i stabilne podloge za financiranje sporta i ocjenu učinkovitosti rada te uspostava mehanizama mjerljivosti i praćenja koji su razrađeni kroz posebne ciljeve i horizontalne mjere. Horizontalne mjere odnosile bi se na razvoj ljudskih potencijala u smislu usavršavanja postojećeg i stvaranja novog potrebnog stručnog kadra, stvaranje uvjeta za bavljenje sportom i rekreacijom svim građanima te stvaranje uvjeta za nesmetan razvoj mladih i darovitih sportaša, kao i omogućavanje vrsnim i vrhunskim sportašima uvjeta za postizanje vrhunskih sportskih postignuća.

\section{Pravni izvori sportskog prava kao okvir za izradu strategija razvoja sporta u jedinicama lokalne samouprave}

\subsection{Sportsko pravo - pojam i izvori}

Sportsko pravo se afirmiralo u zadnjim desetljećima kao mlada pravna disciplina, te se obično definira kao skup pravnih normi ili pravnih pravila kojima se uređuju sportsko-pravni odnosi, koji predstavljaju one pravne odnose u koje pravni subjekti stupaju u svezi s normama objektivnog sportskog prava. ${ }^{5} \mathrm{Uz}$ ovu definiciju u objektivnom smislu, sportsko pravo u subjektivnom smislu predsta-

Cit. KAČER, H., Uvod i osobe u športu, u CRNIĆ, I. i dr., (Uvod u) športsko pravo, Inženjerski biro, Zagreb, 2009., str. 3. 
vlja ovlaštenje koje za pojedini pravni subjekt proizlazi iz normi objektivnog sportskog prava. ${ }^{6}$

Pravni okvir za izradu strategije razvoja sporta na lokalnoj razini čine pravni izvori sportskog prava kojima se uređuje područje sporta i sportske rekreacije, a samim tim i stvaraju bolji uvjeti za razvoj sporta i sportske rekreacije odnosno uspješno obavljanje sportskih aktivnosti i podizanje pravne sigurnosti sportaša i sportskih udruga.

Ovi pravni izvori sportskog prava mogu biti:

- formalni (pravni propisi) i neformalni (običaji, sudska praksa, znanost),

- međunarodni, europski i nacionalni,

- državni i autonomni,

- izravni i supsidijarni.

\subsection{Međunarodni i europski izvori sportskog prava}

Osnovni pravni dokumenti koji definiraju sport na međunarodnoj razini i razini Europske unije te Vijeća Europe su Olimpijska povelja (2011.), Međunarodna povelja o tjelesnom odgoju i športu (UNESCO, 1978.), Europska povelja o sportu (1992. i 2001.), Konvencija Vijeća Europe o integriranom pristupu sigurnosti, zaštiti i uslugama na nogometnim utakmicama i drugim sportskim priredbama (CETS-218., 2017.), Svjetski antidopinški kodeks, ${ }^{7}$ Etički kodeks (2013.), Bijela knjiga o sportu Europske komisije (2007.), Deklaracija o sportu (koja je bila pridodana Ugovoru iz Amsterdama 1997. i Ugovoru iz Nice 2000.) te Lisabonski ugovor (2009.) kojim je sport po prvi put dobio svoje mjesto u primarnom pravu EU-a jer je u istom eksplicitno priznata socijalna i kulturna funkcija sporta. ${ }^{8}$

6 Tako KAČER, H. (ur.), Sportsko pravo, Pravni fakultet Sveučilišta u Splitu, Split, 2018., str. 15.

Svjetski antidopinški kodeks (The World Anti-Doping Code) je prvi put usvojen 2003. godine i stupio je na snagu 2004. Nakon toga je četiri puta mijenjan, prvi put stupa na snagu 1. siječnja 2009., drugi put stupa na snagu 1. siječnja 2015., treći put stupa na snagu 1. travnja 2018. (izmjene usklađenosti) i četvrti put od 1. lipnja 2019. (izvještavanje o određenim endogenim tvarima kao atipični nalazi). Revidirani Svjetski antidopinški 2021 kodeks je na snazi od 1. siječnja 2021., te je dostupan na web-stranici https://www.hoo.hr/ images/dokumenti/antidopinske-aktivnosti/2020/2021_wada_code.pdf. (posjećeno 16. 11. 2021.).

8 Detaljnije BAČIĆ, A., BAČIĆ, P., Lisabonski ugovor i novi start europskog sportskog prava, Zbornik radova Pravnog fakulteta u Splitu, 48, 4., 2011., str. 681. - 702. 
Olimpijska je povelja $(\mathrm{OP})^{9}$ kodifikacija temeljnih načela olimpizma, pravila i dopunskih propisa koje je usvojio Međunarodni olimpijski odbor (MOO), a koji upravlja organizacijom, djelovanjem i radom olimpijskog pokreta i utvrđuje uvjete za proslavu olimpijskih igara.

Olimpijska povelja je zadnji put revidirana 8. kolovoza 2021., te ima tri glavne svrhe:

a) kao osnovni instrument konstitucijske prirode, izlaže i podsjeća na temeljna načela i bitne vrijednosti olimpizma;

b) služi kao statut Međunarodnog olimpijskog odbora;

c) definira glavna recipročna prava i obveze triju glavnih sastavnih dijelova olimpijskog pokreta, tj. Međunarodnog olimpijskog odbora, međunarodnih saveza i nacionalnih olimpijskih odbora, kao i organizacijskih odbora olimpijskih igara koji se moraju pridržavati Olimpijske povelje.

Uz Olimpijsku povelju, upućujemo i na značenje Međunarodne povelje o tjelesnom odgoju, tjelesnoj aktivnosti i sportu, donesene od UNESCO-a 1978., a revidirane 2015. Ova Povelja u čl. 1. inaugurira pravo na sport kao temeljno ljudsko pravo kada u čl. 1. navodi: „Svako ljudsko biće ima temeljno pravo na tjelesni odgoj, tjelesnu aktivnost i sport, bez diskriminacije po osnovu narodnosti, spola, seksualne orijentacije, jezika, religije, političkog ili drugog mišljenja, nacionalnog ili socijalnog porijekla, imovine ili po bilo kom drugom osnovu." Dakle, kako se radi o pravu na sport kao temeljnom ljudskom pravu, ono mora biti dostupno svima bez ikakve razlike po bilo kojem osnovu. ${ }^{10}$ Svako mora imati sve mogućnosti, u skladu s nacionalnom sportskom tradicijom, na tjelesni odgoj i bavljenje sportom, da razvija svoju tjelesnu spremnost i ostvari nivo sportskih rezultata koji su u skladu s njegovim talentima i sposobnostima. Posebne mogućnosti se moraju pružiti mladima, uključujući i djecu predškolskog uzrasta, starima, i hendikepiranima da razviju, u potpunosti, svoje osobe kroz tjelesni odgoj i sportske programe prilagođene njihovim zahtjevima. ${ }^{11}$

Vijeće Europe donijelo je Europsku sportsku povelju (Preporuka br. R (92); usvojena 1992., revidirana 2001.), koja u čl. 2. određuje sport kao sve oblike fizičke aktivnosti koji kroz neorganizirano ili organizirano sudjelovanje, imaju za cilj

9 Zadnja verzija Olimpijske povelje (Olympic Chater) iz 2021. dostupna je na mrežnoj stranici https://stillmed.olympics.com/media/Document\%20Library/OlympicOrg/General/ EN-Olympic-Charter.pdf (posjećena 19. 12. 2021.). uporedno pravo, Beograd, god. 61., br. 3., 2017., str. 135. 
izražavanje ili poboljšavanje fizičke spremnosti i mentalnog blagostanja, stvaranje društvenih odnosa ili postizanje rezultata na natjecanjima svih razina. ${ }^{12}$

Europskom poveljom o sportu definirano je kako će države potpisnice poduzeti odgovarajuće mjere kako bi se svim građanima omogućilo bavljenje sportom, te će se iskoristiti i dodatne mjere kako bi se posebno mladima koji iskazuju sposobnost ili osobama koje su hendikepirane omogućilo da se stvarno koriste tim mogućnostima. Poveljom se potiče poduzimanje odgovarajućih mjera radi razvijanja tjelesne sposobnosti mladih kako bi im se omogućilo stjecanje osnovnih sportskih i tjelesnih sposobnosti, te da se potakne sportska aktivnost, naročito:

- jamčeći svim učenicima korištenje sportskih programa, rekreativnih aktivnosti i tjelesnog odgoja, nužnih ustanova te vremena i prostora predviđenog u tu svrhu,

- jamčeći obuku kvalificiranih školskih nastavnika za ovo područje;

- nudeći odgovarajuće mogućnosti za nastavak bavljenja sportom nakon završetka obveznog školovanja;

- potičući razvoj odgovarajućih veza između škola ili drugih obrazovnih institucija, školskih sportskih klubova i lokalnih sportskih klubova;

- olakšavanjem i razvojem korištenja sportskih kapaciteta od škola i lokalne zajednice;

- poticanjem klime u kojoj roditelji, nastavnici, treneri i lideri stimuliraju mlade da redovno prakticiraju bavljenje sportom i tjelesnom aktivnošću;

- omogućujući obrazovanja iz sportske etike, od razine osnovnih škola nadalje.

Navedenom Poveljom utvrđena je važnost unaprjeđenja sportske djelatnosti kroz osiguravanje odgovarajućih ustanova, različitih programa i stručnih instruktora, voditelja ili animatora te kako posebnu pozornost treba posvetiti eksplicite navedenim aktivnostima (otkrivanje i praćenje darovitih, stavljanje na raspolaganje odgovarajuće ustanove, pružanje pomoći i podrške sportašima u suradnji s medicinskim i sportskim znanostima, unaprjeđenje treniranja na znanstvenim temeljima, formiranje trenera i osoba odgovornih za struku, pomaganje klubovima da osiguraju prikladne strukture i natjecateljsko tržište).

Poveljom je uređeno i pitanje podrške vrhunskom profesionalnom sportu, unaprjeđenje i daljnje obrazovanje osoba koje djeluju u sportu, načelo trajnog ra-

12 Vidi kod NEDIĆ, T., ŠKREBIĆ, M. M.:, Definiranje sporta u hrvatskim i međunarodnim pravnim aktima: na sjecištu prava i filozofije, Stud. ethnol. Croat., vol. 32., Zagreb, 2020., str. 157. 
zvoja sporta, informiranje i istraživanje u sportu, financiranje te međunarodna suradnja.

Na razini Vijeća Europe usvojeni su i sljedeći dokumenti: Europska konvencija o nasilju i nedoličnom ponašanju gledatelja na športskim priredbama, posebice na nogometnim utakmicama (1985., ETS br. 120.), Konvencija protiv dopinga u sportu (1989., ETS br. 135.), Konvencija Vijeća Europe o manipulaciji sportskim natjecanjima od 18. 9. 2014., Preporuka CM/Rec(2015)2 Odbora ministara/ministrica Vijeća Europe državama članicama o rodno osviještenoj politici u sportu (21. 1. 2015.).

Europska konvencija protiv dopinga u sportu je međunarodni pravni instrument u borbi protiv dopinga koji je zapreka sportskoj etici i prijetnja zdravlju sportaša. Konvencija je nastala 1989. godine, a 2002. godine joj se pridružuje dodatni protokol.

U svojim konstitucijskim odredbama države potpisnice Konvencije su se obvezale da će: osnovati državna koordinacijska tijela, smanjiti trgovinu supstancijama za doping i upotrebu nedopuštenih sredstava za doping, pojačati kontrolu dopinga i poboljšati tehnike otkrivanja, podupirati edukaciju i programe podizanja svijesti, jamčiti efikasnost sankcija poduzetih protiv prijestupnika, surađivati sa sportskim organizacijama na svim razinama, uključujući i međunarodne, koristiti ovlaštene antidoping laboratorije. ${ }^{13}$ Republika Hrvatska prihvatila je Konvenciju sukcesijom 1993. godine.

Konvencija Vijeća Europe o manipulaciji sportskim natjecanjima sklopljena je u Magglingenu 18. rujna 2014. Konvenciju je do sada potpisalo 37 država članica Vijeća Europe, među kojima je i Republika Hrvatska. Ratio ove Konvencije je olakšati nacionalnu koordinaciju i međunarodnu suradnju u borbi protiv manipulacije rezultatima sportskih natjecanja. Cilj je zaštititi integritet sporta i sportsku etiku u skladu s načelom autonomije sporta kroz sprječavanje, otkrivanje i sankcioniranje manipulacije nacionalnim i međunarodnim sportskim natjecanjima. Promovira se nacionalna i međunarodna suradnja u borbi protiv manipulacije rezultatima sportskih natjecanja između tijela javnih vlasti, kao i organizacija koje se bave sportom i sportskim klađenjem. ${ }^{14}$

Temeljni cilj Europske konvencije o nasilju i nedoličnom ponašanju gledatelja na sportskim priredbama, posebno na nogometnim utakmicama (European Convention on Spectator Violence and Misbehaviour at Sports Events and in

13 Citat s web-stranice https://mint.gov.hr/vijece-europe-epas/21717 (posjećeno 15. 11. 2021.).

14 Loc. cit. 
particular at Football Matches), usvojene 1985. godine, jest sprečavanje i nadzor nasilja i nedoličnog ponašanja od gledatelja, kao i osiguranje sigurnosti gledatelja tijekom sportskih događaja. Republika Hrvatska prihvatila je Konvenciju sukcesijom 1993. godine. Od 1985. godine se promijenio pristup organizaciji sportskih događaja pa je i Konvencija, kao odraz stvarnog stanja, upotpunila svoj sadržaj u novoj Konvenciji o integriranom pristupu sigurnosti, zaštiti i uslugama na nogometnim utakmicama i drugim sportskim priredbama (2016.). Države koje ratificiraju novu konvenciju istodobno će otkazati Europsku konvenciju o nasilju i nedoličnom ponašanju gledatelja na sportskim priredbama, posebno na nogometnim utakmicama. ${ }^{15}$

I u osnivačkim aktima Europske unije nalazimo pravnu regulaciju sporta. Posebice od Lisabonskog sporazuma iz 2009. Europska unija postaje nadležna za razvoj politike zasnovane na dokazima te za poticanje suradnje i upravljanje inicijativama kojima se podupiru tjelesna aktivnost i sport diljem Europe. Tako člankom 165. UFEU-a propisuje se da djelovanje Unije ima cilj razvijanje europske dimenzije u sportu, između ostalog, promicanjem pravednosti i otvorenosti na sportskim natjecanjima te suradnje među tijelima odgovornima za sport. $\mathrm{Na}$ temelju Ugovora iz Lisabona Europska unija je u skladu s člankom 6. točkom (e) Ugovora o funkcioniranju Europske unije (UFEU) nadležna za potporu ili dopunu djelovanja država članica u području sporta, dok se u članku 165. stavku 1. utvrđuju detalji sportske politike te se navodi da „Unija doprinosi promidžbi europskog sporta, vodeći pritom računa o specifičnoj prirodi sporta, njegovim strukturama koje se temelje na dobrovoljnim aktivnostima te njegovoj društvenoj i obrazovnoj ulozi”. U članku 165. stavku 2. upućuje se na „razvijanje europske dimenzije u sportu promicanjem pravednosti i otvorenosti na sportskim natjecanjima i suradnje među tijelima odgovornima za sport te zaštitom tjelesnog i moralnog integriteta sportaša i sportašica, osobito najmlađih". Osim toga, u članku 165. UFEU-a poziva se Uniju i države članice da promiču suradnju s međunarodnim organizacijama u području sporta, osobito s Vijećem Europe.

$\mathrm{Na}$ razini Europske unije u Bijeloj knjizi Europske komisije o sportu (2007.) $)^{16}$ ističe se važan doprinos sporta gospodarskoj i socijalnoj koheziji i integriranijim društvima iskorištavanjem potencijala koji sport ima za socijalnu uključenost, integraciju i jednake mogućnosti; i u kojoj se, među ostalim, naglašava, da rasizam i ksenofobija te izrabljivanje mladih igrača nisu u skladu sa zajedničkim vrijednostima EU-a.

$15 \quad$ Ibid.

16 White Paper on Sport, Commission of the European Communities, Brussels, 11. 7. 2007., COM (2007) 391 Final, nalazi se na web-stranici: http://ec.europa.eu/sport/white-paper/ index_en.htm. 21.3. 2015. 
Nadalje, Vijeće Europske unije i predstavnici vlada država članica donijeli su Zaključke Vijeća i predstavnika vlada država članica koji su se sastali u okviru Vijeća o promicanju zajedničkih vrijednosti EU-a putem sporta $(2018 / \mathrm{C} 196 / 06) .{ }^{17} \mathrm{U}$ ovom dokumentu potencira se kako u skladu s člankom 165. Ugovora o funkcioniranju Europske unije upravo Unija doprinosi promicanju pitanja u području europskog sporta, vodeći pritom računa o posebnoj prirodi sporta, njegovim strukturama koje se temelje na dobrovoljnim aktivnostima te njegovoj društvenoj i obrazovnoj ulozi. Sport je dio programa Europske unije Erasmus+ od 2011.

Na razini Europske unije važno je uputiti i na sljedeće dokumente:

- Rezolucija Vijeća i predstavnika vlada država članica, koji su se sastali unutar Vijeća, o planu rada Europske unije u području sporta (1. srpnja 2017. - 31. prosinca 2020.) (SL C 189, 15. 6. 2017., str. 5.).

- Zaključci Vijeća o ulozi rada s mladima u podupiranju razvoja ključnih životnih vještina mladih koje im olakšavaju uspješan prijelaz u odraslu dob, aktivno građanstvo i radni život (SL C 189, 15. 6. 2017., str. 30.).

- Zaključci Vijeća i predstavnika vlada država članica, koji su se sastali u okviru Vijeća, o sprečavanju radikalizacije koja vodi u nasilni ekstremizam (SL C 467, 15. 12. 2016., str. 3.).

- Zaključci Vijeća i predstavnika vlada država članica, koji su se sastali unutar Vijeća, o ulozi sektora mladih u integriranom i međusektorskom pristupu sprečavanju i suzbijanju nasilne radikalizacije mladih (SL C 213, 14. 6. 2016., str. 1.).

- Zaključci Vijeća i predstavnika vlada država članica, koji su se sastali u okviru Vijeća, o ulozi trenera u društvu (SL C 423, 9. 12. 2017., str. 6.).

Vijeće europskih ministara sporta donijelo je 1. prosinca 2020. Plan rada EU-a u području sporta (2021. - 2024.). Tjelesna aktivnost ima istaknuto mjesto u tom planu, a ulaganje u sport i zdravstveno usmjerenu tjelesnu aktivnost, uključujući stvaranje mogućnosti za sport za sve generacije, navedeno je kao ključni prioritet. Jedan od ciljeva tog plana je ojačati „oporavak i otpornost sektora sporta na krize u razdoblju tijekom i nakon pandemije bolesti COVID-19”.

Upućujemo i na posebnu poziciju Suda Europske unije koji je razvio važnu sudsku praksu koja ima snažan učinak na svijet sporta. ${ }^{18}$

17 Službeni list EU, C 196/23, od 8. 6. 2018.

„Još 1974. godine Europski sud pravde odlučio je da je komunitarno pravo primjenjivo na sport kao gospodarsku djelatnost u smislu člana 2. Ugovora o Europskoj zajednici (EZ). Zapravo, Europski sud pravde je presudio da se sport podvodi pod odredbe komunitarnog 


\subsection{Nacionalni izvori sportskog prava u Republici Hrvatskoj}

\subsubsection{Ustav Republike Hrvatske}

Pravno uređenje sporta temelji se na hrvatskoj sportskoj tradiciji, tradiciji zakonskog reguliranja sporta te na članku 69. stavku 5. Ustava Republike Hrvatske prema kojem „...država potiče i pomaže skrb o tjelesnoj kulturi i sportu“. Člankom 133. stavkom 3. Ustava Republike Hrvatske određeno je da pravo na lokalnu samoupravu obuhvaća pravo odlučivanja o lokalnim potrebama i interesima građana, a među tim potrebama i interesima istaknut je i sport. ${ }^{19}$

Iz ovog je razvidno da u Republici Hrvatskoj pravo na sport nije eksplicite zajamčeno kao temeljno ljudsko pravo, kao što takvu odredbu ne sadrži ni većina ustava europskih država. Ni hrvatski Zakon o sportu ne navodi pravo na sport kao temeljno ljudsko pravo, iako u čl. 1. st. 3. sadrži odredbu sličnu onoj iz Međunarodne povelje o tjelesnom odgoju, tjelesnoj aktivnosti i sportu (UNESCO, 1978., 2015.): „Sport mora biti jednako dostupan svima bez obzira na dob, rasu, spol, spolnu orijentaciju, vjeru, nacionalnost, društveni položaj, političko ili drugo uvjerenje. ${ }^{“ 20}$

\subsubsection{Zakon o sportu}

Sportska djelatnost u Republici Hrvatskoj regulirana je prvenstveno Zakonom o sportu (NN 71/06, 124/10, 124/11, 86/12, 94/13, 85/15, 19/16, 98/19,

prava kada se sportske aktivnosti i delatnosti obavljaju kao gospodarske (komercijalne) aktivnosti. Takvo opredjeljenje, koje nije predstavljalo samo pravno tumačenje Suda, već i političku odluku i vrijednosni sud o suvremenom sportu, kasnije je potvrđeno i u slučajevima Dona, Bosman, Deliege i Lethonen, a doprinjelo je daljoj komercijalizaciji sporta, ne samo u EU već i u čitavoj Europi.“ Cit. ŠUPUT, D., Nastajanje sportskog prava Evropske unije, Strani pravni život, Institut za uporedno pravo, Beograd, god. 59., br. 2., 2015., str. 101. Detaljnije o utjecaju sudske prakse na regulaciju odnosa u području sporta i potrebu uvođenja posebog specijaliziranog sudišta v. VULETA, D., Sudska regulacija pravnih odnosa na području sportskog prava de lege ferenda, Zbornik radova Pravnog fakulteta u Splitu, god. 52, 4/2015., str. 1139. - 1157.

CRNIĆ, J., IVANČIĆ-KAČER, B., Ustav i šport, u: CRNIĆ, J. i dr., (Uvod) u športsko pravo, Inženjerski biro, Zagreb, 2009., str. 40.

Da pravo na sport predstavlja temeljno ljudsko pravo svjedoči i Olimpijska povelja u poglavlju o Temeljnim načelima olimpizma: „4. Bavljenje sportom je ljudsko pravo. Svakom pojedincu mora biti omogućeno bavljenje sportom, bez diskriminacije bilo koje vrste i u olimpijskom duhu, što zahtijeva obostrano razumijevanje u duhu prijateljstva, solidarnosti i fair play-a." Detaljnije MESTRE, A. M., The Law of the Olymic Games, Den Haag: TMC Asser Press, 2009. 
47/20 i 77/20), te Zakonom o udrugama (NN 74/14, 70/17 i 98/19), te drugim zakonima koji se tiču sportske djelatnosti i neposredno utječu na provedbu sporta.

Zakon o sportu u samostalnoj Hrvatskoj prvi put je donesen 1990. godine, zatim 1992., značajno je mijenjan 1995., a nova verzija usvojena je 1997. godine, pa potom važeći Zakon o sportu iz 2006.

Dakle, od osamostaljenja Republike Hrvatske trenutno je na snazi četvrti Zakon o sportu, i to onaj iz 2006. godine, kojim se je posebno htjelo razlučiti amaterski od profesionalnog sporta i riješiti status profesionalnih sportaša. Daljnja veća novina važećeg Zakona je uvođenje u sustav sporta i sportskih natjecanja sportskih dioničkih društava kao trgovačkih društava po uzoru na zemlje članice EU. ${ }^{21} \mathrm{Za}$ kon o sportu sportsko dioničko društvo određuje kao sportski klub koji se osniva, djeluje i prestaje prema Zakonu o trgovačkim društvima (NN 111/93, 34/99, 52/00, 118/03, 107/07, 146/08, 137/09, 125/11, 152/11, 111/12, 68/13, 110/15 i 40/19) i drugim propisima koji se primjenjuju na dionička društva, ako ovim Zakonom nije drukčije određeno, s time što se na sportsko dioničko društvo ne primjenjuju odredbe Zakona o preuzimanju dioničkih društava (NN 109/07, 36/09, 108/12, 90/13, 99/13 i 148/13) o obveznoj ponudi za preuzimanje, ${ }^{22}$ Sportsko dioničko društvo nije jedini oblik trgovačkog društva u kojem se sportske djelatnosti mogu obavljati. To je doduše jedini oblik trgovačkog društva u kojem se može obavljati sportska djelatnost sudjelovanja u sportskim natjecanjima, dok se druge sportske djelatnosti (npr. sportska rekreacija, upravljanje i održavanje sportske građevine i dr.) mogu obavljati i u drugim oblicima trgovačkih društava koje generalno uređuje Zakon o trgovačkim društvima (npr. društvo s ograničenom odgovornošću, jednostavno društvo s ograničenom odgovornošću, klasično dioničko društvo, javno trgovačko društvo, komanditno društvo). ${ }^{23}$

Važećim Zakonom o sportu definirano je sljedeće: sustav sporta, osobe u sustavu sporta, sportske djelatnosti, stručni poslovi u sportu, statusna pitanja sportaša, pitanja sportskih klubova, sport osoba s invaliditetom, sport djece i mladeži,

21 ČUSTONJA, Z., Ustroj športa i športsko zakonodavstvo, u „Temeljna načela i smjerice razvoja športa u Republici Hrvatskoj“ - radni materijal, Nacionalno vijeće za šport, Zagreb, veljača 2011., str. 63.

Više o sportskom dioničkom društvu kod PETROVIĆ, S., Športsko dioničko društvo, u: BUTORAC, S. S. et al., Novi Zakon o športu i aktualna praksa iz područja športa i športskih djelatnosti, Inženjerski biro, Zagreb, 2007., str. 61. - 62.; JELUŠIĆ, D., Sportsko dioničko društvo, dostupno na mrežnoj stranici http://www.pravnadatoteka.hr/pdf/Sportsko\%20 dioni\%C4\%8Dko\%20dru\%C5\%A1tvo.pdf, te IVKOŠIĆ, M., CERONJA, P., Pravni modeli provođenja postupka obveznog preoblikovanja športskog kluba - udruge u športsko dioničko društvo, Zbornik Pravnog fakulteta u Zagrebu, 59, 1, 2009., str. 125. - 150. 
zdravstvena zaštita sportaša, sportske građevine, javne potrebe u sportu, financiranje sporta, državne nagrade u sportu i drugo.

Sportske djelatnosti, u smislu čl. 18. st. 1. Zakona o sportu, jesu:

- sudjelovanje u sportskom natjecanju,

- sportska priprema,

- sportska rekreacija,

- sportska poduka,

- organiziranje sportskog natjecanja,

- vođenje sportskih natjecanja i

- upravljanje i održavanje sportskom građevinom.

Sportskom djelatnošću smatraju se i organizirane izvannastavne školske sportske aktivnosti i studentske sportske aktivnosti.

U sumnji je li neka djelatnost sportska djelatnost odlučuje nadležno ministarstvo za sport (uz prethodno mišljenje HOO-a). Nacionalna klasifikacija djelatnosti (NN 58/07; NKD 2007) razvrstava subjekte u sportu u jednom odjeljku (93. Sportske djelatnosti te zabavne i rekreacijske djelatnosti) s dvije glavne skupine i šest razreda sportskih djelatnosti:

1. Sportske djelatnosti,

1.1. Rad sportskih objekata,

1.2. Djelatnost sportskih klubova,

1.3. Fitnes centri,

1.4. Ostale sportske djelatnosti,

2. Zabavne i rekreacijske djelatnosti,

2.1. Djelatnosti zabavnih i tematskih parkova,

2.2. Ostale zabavne i rekreacijske djelatnosti.

Sportske djelatnosti su djelatnosti od posebnog interesa za Republiku Hrvatsku (čl. 1. st. 2. Zakona o sportu), a time i za jedinice lokalne samouprave.

Sukladno Zakonu o sportu (čl. 61. st. 1. i 2.) HOO donosi i ažurira opći akt o načelima i donose svoje akte. HOO utvrđuje Nomenklaturu sportova i sportskih grana prema odredbama Zakona o sportu. 
Od svoga donošenja 2006. godine Zakon o sportu je sedam puta dopunjavan i mijenjan, no, navedene izmjene i dopune nisu riješile nedostatke specifične za sustav sporta te je sukladno provedenom postupku prethodne procjene učinaka propisa u 2016. godini novi Zakon o sportu u planu kao reformski zakon. Tijekom ožujka 2017. godine provedena je javna rasprava o Iskazu procjene učinaka propisa i tezama za zakon o sportu. Kao dio postupka procjene učinaka propisa za zakon o sportu, osim javne rasprave o Iskazu o procjeni učinaka propisa i tezama za zakon o sportu, održana je i javna prezentacija navedenog dokumenta. Sveukupno je zaprimljeno 102 mišljenja, primjedbi i prijedloga (e-Savjetovanje i javno izlaganje), od čega je većina prihvaćena.

Novim zakonom o sportu sukladno provedenoj procjeni učinaka namjerava se provesti kategorizacija i vrednovanje sportova, urediti rad sportskih udruga, kao i sustav kontrole te posljedice neispunjavanja obveza od sportskih udruga, podignuti razinu učinkovitosti krovnih sportskih udruženja jasnijim definiranjem javnih potreba u sportu i određivanjem kriterija ograničenja za troškove administracije i upravljanja, koje se financiraju javnim sredstvima. Nadalje, namjerava se uspostaviti učinkovitiji nadzor nad korištenjem proračunskih sredstava za financiranje sporta, uskladiti potrebnu stručnu spremu, odnosno stupanj obrazovanja prema vrsti i složenosti poslova u sportu te njihovo prilagođavanje stvarnim kadrovskim potrebama, ujednačiti i objediniti sve subjekte i podatke u sportu u jedinstvenu evidenciju, urediti pitanje sportskih građevina i mreže sportskih građevina, urediti sustav financiranja velikih međunarodnih sportskih natjecanja u Republici Hrvatskoj utemeljen na jasnim kriterijima, urediti stvarne potrebe za liječnicima propisane specijalnosti, kao i liječničke preglede, propisati sportske stipendije za vrhunske sportaše I. kategorije na državnoj razini, definirati radnopravni status profesionalnih sportaša i trenera uključujući i pitanja povezana s dual karijerom sportaša, omogućiti obavljanje sportskih djelatnosti putem obrta, definirati posljedice osude i kaznenog djela te zapreke i ograničenja za članstvo u tijelima sportskih udruga za natjecanje, sportskih saveza i sportskih dioničkih društava.

\subsubsection{Podzakonski akti u području sporta}

Zakonom o sportu iz 2006. godine predviđeno je donošenje podzakonskih akata u rokovima od mjesec dana do godine od stupanja zakona na snagu.

Na snazi su sljedeći podzakonski akti u području sporta:

- Uredba o kriterijima za dodjeljivanje državnih nagrada za vrhunska sportska postignuća (NN 129/17); 
- Uredba o dodjeljivanju trajnih novčanih mjesečnih naknada osvajačima medalja na olimpijskim igrama, paraolimpijskim igrama, olimpijskim igrama gluhih i svjetskim seniorskim prvenstvima u olimpijskim sportovima i disciplinama (NN 113/13);

- Pravilnik o postupku pred Vijećem sportske arbitraže Hrvatskog olimpijskog odbora (NN 11715, 57/15 i 4/16);

- Pravilnik o priznavanju inozemnih stručnih kvalifikacija iz područja športa (NN 49/17);

- Pravilnik o informacijskom sustavu u sportu (NN 25/19);

- Pravilnik o metodologiji, rokovima za izradu i dostavu, načinu izvršavanja programa javnih potreba, o načinu i rokovima izvještavanja o provedbi programa te o metodologiji izrade financijskog plana javnih potreba (NN 108/17);

- Pravilnik o načinu osnivanja, zadaćama, djelokrugu i načinu rada školskih sportskih društava (NN 13/14);

- Pravilnik o načinu osnivanja, zadaćama, djelokrugu i načinu rada školskih športskih saveza (NN 136/06);

- Pravilnik o Registru profesionalnih športskih klubova (NN 11/07);

- Pravilnik o načinu i rokovima podnošenja akata Povjerenstvu za profesionalne športske klubove (NN 11/07);

- Pravilnik o djelokrugu i načinu rada Povjerenstva za profesionalne športske klubove (NN 11/07);

- Pravilnik o uvjetima za obavljanje obuke ronjenja i športsko-rekreativnog ronjenja (NN 105/00 i 24/03);

- Pravilnik o osposobljavanju osoba koje obavljaju poslove redara na športskim natjecanjima (NN 54/04);

- Pravilnik o mjerilima za dodjelu nagrada sportašima za sportska ostvarenja (NN 46/14 i 9/17);

- Pravilnik o Državnoj nagradi za sport "Franjo Bučar" (NN 30/07);

- Pravilnik o Registru športskih djelatnosti (NN 112/06). ${ }^{24}$

Važno je ukazati i na Uredbu o kriterijima, mjerilima i postupcima financiranja i

$24 \quad$ Više kod BUTORAC, S. S., Podzakonski akti sukladno Zakonu o športu, u: BUTORAC, S. S. et al., Novi Zakon o športu i aktualna praksa iz područja športa $i$ športskih djelatnosti, Inženjerski biro, Zagreb, 2007., str. 153. - 155. 
ugovaranja programa i projekata od interesa za opće dobro koje provode udruge (NN 26/15 i 37/21; na snazi od 17. ožujka 2015. godine).

Uz Zakon o sportu, za regulaciju sporta od iznimne su važnosti i drugi zakoni, prije svega Zakon o udrugama koji definira rad sportskih udruga.

\subsubsection{Drugi zakoni referentni u području sporta}

Područje sporta reguliraju i:

- Zakon o sportskoj inspekciji (NN 86/12, 98/19 i 34/21) i pripadajući podzakonski akti (npr. Pravilnik o službenoj iskaznici i znaku sportskih inspektora - NN 27/13; Pravilnik o obrascima i načinu vođenja očevidnika o obavljenim inspekcijskim pregledima i poduzetim mjerama sportske inspekcije - NN 27/13),

- Zakon o sprječavanju nereda na športskim natjecanjima (NN 117/03, 71/06, 43/09 i 34/11),

- Zakon o proračunu (NN 87/08, 136/12 i 15/15),

- Zakon o udrugama,

- Zakon o trgovačkim društvima, za ustroj i djelovanje sportskih društava,

a na odgovarajući način primjenjuju se i drugi zakoni i podzakonski propisi, osobito oni koji uređuju pitanja udruživanja građana, djelatnosti školstva (npr. Pravilnik o načinu osnivanja, zadaćama, djelokrugu i načinu rada školskih športskih saveza - NN 136/06; Pravilnik o načinu osnivanja, zadaćama, djelokrugu i načinu rada školskih sportskih društava - NN 13/14) i gospodarstva te propisi iz sustava državne uprave (npr. Upute o provođenju nadzora nad stručnim radom u športu - NN 23/91 i 111/97), graditeljstva, financija i zdravstva (npr. Lista tvari zabranjenih u sportu - NN 116/13).

Pravne osobe u sustavu sporta najčešće su ustrojene u obliku udruga koje se upisuju u Registar udruga, u Registar sportskih djelatnosti te u Registar neprofitnih organizacija. Sve sportske udruge i njihovi savezi, kao i ustanove na području sporta, sukladno Zakonu o financijskom poslovanju i računovodstvu neprofitnih organizacija (NN 121/14; na snazi od 1. 1.2015. g.), dužne su se upisati u Registar neprofitnih organizacija (RNO), koji ustrojava i vodi Ministarstvo financija RH. Ovisno o svojim prihodima, odnosno imovini, neprofitne organizacije, pa tako i sportske udruge upisane u RNO, dužne su sastavljati i podnositi financijska izvješća o svom poslovanju. 


\subsubsection{Sportska pravila kao autonomni izvor sportskog prava}

Načelo autonomije sporta jasno se manifestira upravo u pravu sportskih organizacija (udruženja, saveza, federacija) da slobodno ustanovljavaju, mijenjaju i tumače pravila primjerena njihovom sportu, bez bilo kakvog političkog i ekonomskog utjecaja. Ovo polazi od neprijepornosti da svaki sport ima svoja određena pravila igre čije utvrđivanje je u samom biću sporta. ${ }^{25}$ Pretežito je doktrinarno gledište kako sportska pravila nemaju normativni karakter niti mogu prerasti u običajno pravo. Radi se o pravilima koja obvezuju sudionike u sportu, ali državna i sudska tijela nisu vezana ovim pravilima prigodom procjene dopuštenosti nečijeg ponašanja. ${ }^{26}$ Ipak, priroda sportskih pravila neodvojiva je od pravne prirode statuta i drugih općih akata sportskog udruženja koji je adresant tih pravila, pa ako su ista inkorporirana u akte udruženja, ista podliježu sudskoj kontroli.

Sportska pravila mogu biti međunarodnog ili nacionalnog karaktera. Na nacionalnoj razini sportska su pravila ona pravila uređena općim aktima nadležnih nacionalnih sportskih saveza, kojima se uređuje obavljanje sportskih aktivnosti i djelatnosti i ostvarivanje utvrđenih sportskih ciljeva. Nacionalni sportski savezi usklađuju svoja sportska pravila sa sportskim pravilima nadležnog međunarodnog sportskog saveza, koja su pravila višeg ranga i primjenjuju se u slučaju njihove kolizije i neusuglašenosti. ${ }^{27}$

Prema čl. 51. Zakona o sportu, HOO među svojim zadaćama ima i zadatak da provodi i skrbi o primjeni međunarodnih sportskih pravila, te donosi akte u svezi s njihovom primjenom.

Sportska pravila treba razlikovati od normi odnosno akata koje sportska udruženja i drugi subjekti u sportu, posebice klubovi, donose kao svoje opće normativne akte.

\subsubsection{Sudska praksa i pravna znanost u području sportskog prava}

I na području sportskog prava često se javljaju situacije koje zakonodavac nije predvidio, pa prema tome ni riješio općim pravnim pravilom. Čak i u uvjetima iscrpnog reguliranja prava pisanim pravilima, kreativnoj funkciji sudske

25 Cit. ĐURĐEVIĆ, N., Autonomija sporta - obaveznost sportskih pravila međunarodnih sportskih saveza na nacionalnom nivou, Zbornik radova Pravnog fakulteta u Splitu, god. 55., 2., 2018., str. 291.

$26 \quad$ Ibid., str. 292.

27 Loc. cit. 
prakse ostaje bitna uloga $\mathrm{u}$ interpretaciji pravnih pravila, naročito kad se radi o tekstovima koji zbog svoje nepotpunosti, nedorečenosti, praznina ili nedosljednog tretiranja određenih pitanja nužno iziskuju stvaralački doprinos onih koji ih primjenjuju. Stoga stilus curiae igra od davnina važnu ulogu o oživotvorenju pravne norme. Unatoč činjenici što sudska praksa ne predstavlja općevažeći izvor prava, odluke sudova u konkretnim predmetima izvor su prava za subjekte na koje se njihova pravomoćnost odnosi. Sudska odluka djeluje kao izvor prava za same stranke za koje je u konkretnom slučaju donesena (res iudicata facit ius inter partes). Možemo zaključiti da iako sudska praksa nije de iure izvor sportskog prava, ona de facto može biti izvor sportskog prava. Međutim, zapažena velika neujednačenost sudskih odluka u sporovima koji se odnose na sport, kao i njihova iznenađujuća obrazloženja i stavovi mogu imati za posljedicu pravnu nesigurnost i gubitak povjerenja u rad sudova.

Punopravnim članstvom Republike Hrvatske u Europskoj uniji situacija se donekle mijenja. Pravnostvaralačka praksa Suda pravde EU-a kao izvor prava ima posebno značenje s obzirom da popunjava praznine te harmonizira prakse nacionalnih sudova država članica sukladno postavljenim standardima europske supranacionalne legislative. Upravo zbog toga se instituti sportskog prava ne mogu analizirati bez prakse europskih sudova kao nezaobilaznog izvora prava, pogotovo što je Republika Hrvatska ostvarila 2013. punopravno članstvo u Europskoj uniji. Posebice stoga što sudska praksa Suda pravde Europske unije ima učinak erga omnes, tu je praksu nužno uzimati u obzir i na području sportskog prava, posebice onu u presudama C-36/74 Walrave and Koch v Association Union Cyliste Internationale ECR [1974] 1405, C-13/76, Gaetano Donà v Mario Mantero, ECR [1976] 1333, te C-415/93, Union Royale Belge des Societés de Football Association and other v Bosman, ECR [1995] I-4921, C-176/96, Jyri Lehtonen and Castors Canada Dry Namur-Braine v Fédération Royale Belge des Sociétés de Basketball, ECR [2000] I-2681, C-519/04, Meca-Medina and Majcen v Commission, ECR [2006] I-6991, C-403/08, C-429/08, Football Association Premier League and Karen Murphy and others, ECR [2011] 0000, te C-325/08, Olympique Lyonnais SASP $v$ Olivier Bernard, Newcastle United FC, ECR [2008] I-4139. ${ }^{28}$

Značajno je gledište iz presude u slučaju Bosman po kojemu su profesionalni sportaši u momčadskim sportovima definirani radnicima u smislu čl. 45 . UFEU-a, pogotovo ako se uzme u obzir trajnost obavljanja rada, čime se slijedi

$28 \quad$ Usp. SMOKVINA, V., RUBEŠA, T., Gospodarska sloboda kretanja profesionalnih sportaša kao radnika u Europskoj uniji s naglaskom na pravne izvore i odluku Bernard, Zbornik Pravnog fakulteta u Zagrebu, Vol. 64, 2014., br. 3., str. 393. - 423. 
temeljno gledište iz predmeta Lawrie-Blum C-66/85, Lawrie-Blum v Land Baden-Würtemberg, ECR [1986] 212, u kojemu je Sud pravde EU ustvrdio osnovne karakteristike radnika: da tijekom određenog vremenskog razdoblja obavlja određene poslove koji imaju određenu ekonomsku vrijednost za drugog i prema njegovim uputama, a za što zauzvrat dobije naknadu za rad (engl. remuneration) ${ }^{29}$ Čl. 57(2). UFEU-a u pogledu slobode pružanja usluga stavlja naglasak na „privremeno obavljanje“, a profesionalni sportaši u pravilu potpisuju ugovore na razdoblje od jedne do pet godina. ${ }^{30}$

Uz sudsku praksu u ovom području referentna je i arbitražna praksa arbitražnih sportskih sudova, kako nacionalnih (npr. Vijeće sportske arbitraže HOO-a ${ }^{31}$ ), tako i međunarodnih (npr. Arbitražni sud za sport - CAS ${ }^{32}$ ).

Pravna znanost, kao i sudska praksa, ne predstavlja primarni neposredni izvor radnog prava, ali u bitnome snagom argumentacije i autoriteta može doprinijeti razumijevanju sporova popunjavanjem pravnih praznina. Budući da propisi sportskog prava, kao uostalom i većina drugih, zaostaju za novim životnim situacijama koje traže pravnu regulativu, pravna doktrina usklađenije prati te pojavnosti nego zakonodavac. Na području sportskog prava pravna doktrina ima iznimnu ulogu jer se radi o relativno mladoj grani prava. ${ }^{33}$

29 Cit. prema BILIĆ, A., SMOKVINA, V., Ugovor između profesionalnog nogometaša i kluba - ugovor radnog ili građanskog prava?, Zbornik radova Pravnog fakulteta u Splitu, 49, 4, 2012., str. 845.

Prema čl. 2. st. 2. Pravilnika o statusu i transferu igrača FIFA-e profesionalac je igrač koji ima pisani ugovor s klubom i koji je plaćen za svoje nogometne aktivnosti više nego što to iznose troškovi njegovog igranja. O problemima definiranja profesionalnog sportaša u RH detaljnije kod JELUŠIĆ, D., Vrste ugovora u hrvatskom sportskom pravu, dostupno na mrežnoj stanici http://www.pravnadatoteka.hr/pdf/Vrste\%20ugovora\%20u\%20hrvatskom\%20sportskom\%20pravu.pdf, str. 3. - 4.

V. Pravilnik o postupku pred Vijećem sportske arbitraže Hrvatskog olimpijskog odbora (NN 21/15, 57/15, 4/16).

V. odluke u slučajevima Webster, CAS 2007./A/1298, Matuzalem, CAS 2008./A/15191520, De Sanctis, CAS 2010./A/2145 \& 2146 \& 2147., Gerard Piqué, CAS 2004/a/691, Cheick Tidiane Sarr, CAS 2005/A/838, Magnus Troest, CAS 2006/A/1177. Detaljnije BILIĆ, A., Jednostrani raskid ugovora o radu između nogometaša i kluba bez opravdanog razloga, Zbornik radova Pravnog fakulteta u Splitu, 52, 2, 2015., str. 500. - 503.

33 V. KAČER, H., PERKUŠIĆ, A., IVANČIĆ-KAČER, B., Postoji li u Republici Hrvatskoj (kvalitetno) sportsko pravo, Zbornik radova Pravnog fakulteta u Splitu, 49, 4, 2013., str. 733. 


\section{Javne potrebe u sportu na lokalnoj razini i njihovo financiranje}

U Zakonu o sportu definirane su, između ostalog, javne potrebe u sportu na državnoj i lokalnoj razini, osnivanje i djelokrug sportskih zajednica te programske aktivnosti i ciljevi javnih potreba u sportu i njihovo financiranje i sufinanciranje koje je propisano i Zakonom o udrugama i Zakonom o proračunu. Zakonom o sportu propisano je da su sportske djelatnosti od posebnog interesa za Republiku Hrvatsku, a time i za jedinice lokalne samouprave.

Članak 74. Zakona o sportu jasno definira način i osnovu financiranja sporta. ${ }^{34}$ Prema Zakonu o sportu, osnovu financiranja sporta čine prihodi koje pravne i fizičke osobe koje obavljaju sportsku djelatnost ostvare obavljanjem sportske djelatnosti, ${ }^{35}$ članarine koju ostvaruju sportske udruge, kao i dio prihoda od priređivanja igara na sreću i sredstava kojima jedinice lokalne i područne (regionalne) samouprave i Grad Zagreb te država pomažu obavljanje sportskih djelatnosti. Republika Hrvatska, jedinice lokalne i područne (regionalne) samouprave i Grad Zagreb utvrđuju javne potrebe u sportu i za njihovo ostvarivanje osiguravaju financijska sredstva iz svojih proračuna u skladu sa Zakonom o sportu.

Odredbom čl. 76., st. 1. t. 1.-9. Zakona o sportu, javne su potrebe u sportu određene kao "aktivnosti, poslovi i djelatnosti od značaja za jedinicu samouprave", u svezi s:

1. poticanje i promicanje sporta,

2. provođenje sportskih aktivnosti djece, mladeži i studenata,

3. djelovanje sportskih udruga, sportskih zajednica i saveza,

4. sportska priprema, domaća i međunarodna natjecanja te opća i posebna zdravstvena zaštita sportaša,

5. zapošljavanje osoba za obavljanje stručnih poslova u sportu,

6. sportsko-rekreacijske aktivnosti građana,

7. sportske aktivnosti osoba s teškoćama u razvoju i osoba s invaliditetom,

8. planiranje, izgradnja, održavanje i korištenje sportskih građevina značajnih za jedinicu lokalne i područne (regionalne) samouprave i Grada Zagreba,

$34 \quad$ Usp. ZUBER, M., Financiranje športa, u: BUTORAC, S. S. et al., Novi Zakon o športu $i$ aktualna praksa iz područja športa i športskih djelatnosti, Inženjerski biro, Zagreb, 2007., str. 233. - 250.

35 Jedan od izvora financiranja sporta je i sponzorstvo. Više kod JAGODIC, T., MATEŠA, Z., Basic Elements of a Sponsorship Contract in Sport, Zbornik Pravnog fakulteta u Splitu, 55, 2, 2018., str. 275. - 287. 
9. provođenje i financiranje znanstvenih i razvojnih projekata elaborata i studija u funkciji razvoja sporta.

Osnovni ciljevi programa javnih potreba u sportu na razini jedinice lokalne samouprave, koji se financiraju sredstvima proračuna određene lokalne jedinice trebali bi biti:

- ulaganje u razvoj mlađih sportaša radi stvaranja široke kvalitativne osnove kao uvjeta daljnjega napretka, odnosno očuvanja dostignute razine kvalitete sporta na lokalnoj razini;

- vrhunska sportska kvaliteta koja potiče razvoj sporta i doprinosi ugledu jedinice lokalne samouprave;

- poticanje uključivanja u sport što većeg broja građana, osobito djece i mladeži.

Slijedom navedenih zakonskih odredbi, kao i odredbi vezanih uz djelokrug sportskih zajednica, propisano je da se radi ostvarivanja zajedničkih interesa u sportu na području jedinica lokalne i područne (regionalne) samouprave i Grada Zagreba osnivaju sportske zajednice. Članovi sportskih zajednica u županijama, Gradu Zagrebu, gradovima i općinama su pravne osobe iz sustava sporta. Članovi sportskih zajednica mogu biti i druge pravne osobe čija je djelatnost značajna za sport i u vezi sa sportom. Sportske zajednice u svom djelokrugu usklađuju aktivnosti svojih članova, potiču i promiču sport u skladu s Nacionalnim programom sporta, osobito sport djece, mladeži i studenata i osoba s invaliditetom, objedinjuju i usklađuju programe sporta te predlažu program javnih potreba $\mathrm{u}$ sportu i sudjeluju u njegovu ostvarivanju, skrbe o kategoriziranim sportašima i svojim aktima uređuju opseg i način ostvarivanja njihovih prava te sudjeluju u stvaranju uvjeta za njihovu pripremu za olimpijske igre, svjetska i europska prvenstva te druga velika međunarodna natjecanja, surađuju u ostvarivanju programa Hrvatskoga olimpijskog odbora, odnosno Hrvatskoga paraolimpijskog odbora i Hrvatskoga sportskog saveza gluhih, promiču stručni rad u sportu i sudjeluju u skrbi o javnim sportskim građevinama. Također je propisano da se na razini jedinica lokalne i područne (regionalne) samouprave i Grada Zagreba može osnovati samo jedna sportska zajednica.

\section{Sportske građevine i prostorno planiranje na lokalnoj razini}

Prema čl. 65. Zakona o sportu, sportskim građevinama smatraju se uređene i opremljene površine i građevine u kojima se provode sportske djelatnosti, a koje osim općih uvjeta propisanih posebnim propisima za te građevine zadovoljavaju 
i posebne uvjete u skladu s odredbama ovoga Zakona. Javnim sportskim građevinama smatraju se građevine koje su u vlasništvu Republike Hrvatske, odnosno u vlasništvu jedinica lokalne i područne (regionalne) samouprave i Grada Zagreba te se trajno koriste $\mathrm{u}$ izvođenju programa javnih potreba $\mathrm{u}$ sportu. ${ }^{36}$

Hrvatski sabor na prijedlog Vlade Republike Hrvatske, koja prethodno pribavlja mišljenje Nacionalnog vijeća za sport, tijela jedinice lokalne i područne (regionalne) samouprave i Grada Zagreba, pripadajućih sportskih zajednica i odgovarajućih sportskih saveza donosi mrežu sportskih građevina. Mrežom sportskih građevina određuje se plan izgradnje, obnove, održavanja i upravljanja sportskim građevinama. Mreža sportskih građevina obvezna je podloga za izradu dokumenata prostornog uređenja. Prostorne uvjete, standarde i normative sportskih građevina obuhvaćenih mrežom sportskih građevina te posebne uvjete za planiranje, programiranje, projektiranje, gradnju, održavanje i sigurnost korisnika sportskih građevina propisuje pravilnikom ministar uz prethodnu suglasnost ministra nadležnog za poslove zaštite okoliša, prostornog uređenja i graditeljstva. U postupku izdavanja lokacijske dozvole za sportsku građevinu tijelo koje izdaje lokacijsku dozvolu pribavlja mišljenje ministarstva o usklađenosti s navedenim uvjetima.

Prema čl. 44. Zakona o prostornom uređenju (NN 153/13, 65/17, 114/18, 39/19 i 98/19), koji predstavlja supsidijarni izvor sportskog prava, izvan građevinskog područja može se planirati izgradnja golf igrališta i drugih sportsko-rekreacijskih igrališta na otvorenom s pratećim zgradama. U izdvojenom građevinskom području izvan naselja te na prostoru izvan građevinskog područja na kojem se namjerava graditi igralište za golf i sportsko-rekreacijsko igralište na otvorenom u pojasu najmanje $100 \mathrm{~m}$ od obalne crte ne može se planirati građenje novih građevina, osim građevina komunalne i prometne infrastrukture koje po svojoj prirodi zahtijevaju smještaj na obali i podzemne infrastrukture, pratećih sadržaja ugostiteljsko-turističke namjene, građevina koje po svojoj prirodi zahtijevaju smještaj na obali (brodogradilišta, luke i sl.), te uređenje javnih površina. Inače, napominjemo kako je Zakon o igralištima za golf (NN 152/08. i 80/10) prestao važiti danom stupanja na snagu Zakona o prestanku važenja Zakona o igralištima za golf (NN 130/11).

U prostoru ograničenja izdvojena građevinska područja izvan naselja ugostiteljsko-turističke i sportske namjene, u kojima se osnovna namjena (smještaj, sport) ostvaruje u izgrađenim strukturama, mogu se planirati na predjelima ma-

36 O javnim sportskim građevinama detaljnije PERKUŠIĆ, A., Športske građevine (objekti), u: CRNIĆ, I. i dr., (Uvod u) športsko pravo, Inženjerski biro, Zagreb, 2009., str. 289. 
nje prirodne i krajobrazne vrijednosti prema kondicijama propisanim čl. 49. Zakona o prostornom uređenju.

Prenamijeniti površinu planiranu za javnu sportsku građevinu, ukloniti ili prenamijeniti javnu sportsku građevinu za namjene koje nisu sportske djelatnosti može se prema čl. 68. Zakona o sportu samo uz suglasnost ministarstva na temelju prethodnog mišljenja sportske zajednice na čijem se području nalazi sportska građevina. Ipak, ova se suglasnost ne može izdati ako jedinica lokalne, odnosno regionalne (područne) samouprave nije planirala odgovarajuću zamjensku površinu i ako investitori prenamjene javne sportske građevine, odnosno vlasnik javne sportske građevine koja se uklanja ne preuzme obvezu i osigura uvjete izgradnje odgovarajuće zamjenske javne sportske građevine. Iznimno, suglasnost se može dati samo ako se radi o građevini od posebnog interesa za Republiku Hrvatsku.

Uz ovaj Zakon treba konzultirati i Pravilnik o prostornim standardima, normativima te urbanističko-tehničkim uvjetima za planiranje mreže športskih objekata (NN 38/91 i 111/97).

Upravljanje javnim sportskim građevinama može se povjeriti i sportskim klubovima i savezima, sportskoj zajednici, ustanovama i trgovačkim društvima registriranima za obavljanje sportske djelatnosti upravljanja i održavanja sportskih građevina (čl. 69. Zakona o sportu).

\section{Zaključak}

Sport je bitan, ne samo za pojedince, nego i za društveni i kulturni razvoj svake zajednice, kako na nacionalnoj, tako i na regionalnoj i lokalnoj razini. Sportsko pravo se sve više afirmira kao samostalna moderna pravna disciplina, posebice kroz razvitak pravne regulative, judikature i pravne doktrine u ovom području uređenja društvenih odnosa. U Republici Hrvatskoj donesen je novi Nacionalni program športa 2019., ali to nije rezultiralo značajnijim brojem lokalnih sredina koje su donijele svoje strategije razvoja sporta na razini županija i gradova. Kao podloga izrade strategije razvoja sporta na lokalnoj razini nužno je odrediti pravni okvir sporta na nacionalnoj i lokalnoj razini. Uz Nacionalni program športa 2019. - 2026., nužno je inicirati revidiranje zakonskog okvira sporta u Republici Hrvatskoj, na tragu temeljnih međunarodnih, europskih i nacionalnih propisa u području sporta. 


\title{
LEGAL SOURCES AND LEGAL BASIS FOR STRATEGIC DOCUMENTS FOR THE DEVELOPMENT OF SPORTS AND SPORTS RECREATION AT THE LOCAL LEVEL IN THE REPUBLIC OF CROATIA
}

\begin{abstract}
The author clearly analyzes the legal framework of international, European and Croatian sports law, as a basis for the development of sports development strategies at the level of local self-government in the Republic of Croatia. As part of the discussion on this topic, insight is given into the reference provisions of the revised Law on Sports and as well as the purpose and goals of the new National Sports Program 2019-2026. The paper finally explores the strategic documents of local and regional self-government units in the Republic of Croatia in the field of sports development and sports recreation, and points to the needs of a new legal and strategic basis at the national level.
\end{abstract}

Keywords: sport, sport strategy, Law on Sport, Olympic Charter, European Sports Charter. 